University of Nebraska - Lincoln

DigitalCommons@University of Nebraska - Lincoln

\title{
Evaluation Of Oviposition Substrates And Organic Infusions On Collection Of Culex In Florida
}

\author{
Sandra Allan \\ USDA-ARS, sandy.allan@ars.usda.gov \\ Ulrich R. Bernier \\ University of Florida, ubernier@gainesville.usda.ufl.edu \\ David Kline \\ United States Department of Agriculture-ARS-Center for Medical
}

Follow this and additional works at: https://digitalcommons.unl.edu/usdaarsfacpub

Part of the Agricultural Science Commons

\begin{abstract}
Allan, Sandra; Bernier, Ulrich R.; and Kline, David, "Evaluation Of Oviposition Substrates And Organic Infusions On Collection Of Culex In Florida" (2005). Publications from USDA-ARS / UNL Faculty. 949. https://digitalcommons.unl.edu/usdaarsfacpub/949
\end{abstract}

This Article is brought to you for free and open access by the U.S. Department of Agriculture: Agricultural Research Service, Lincoln, Nebraska at DigitalCommons@University of Nebraska - Lincoln. It has been accepted for inclusion in Publications from USDA-ARS / UNL Faculty by an authorized administrator of DigitalCommons@University of Nebraska - Lincoln. 


\title{
EVALUATION OF OVIPOSITION SUBSTRATES AND ORGANIC INFUSIONS ON COLLECTION OF CULEX IN FLORIDA
}

\author{
SANDRA A. ALLAN, ULRICH R. BERNIER AND DANIEL L. KLINE
}

\author{
USDA/ARS, Center for Medical, Agricultural, and Veterinary Entomology, $1600 \mathrm{~h} 7700$ sW 23 rd Drive.
} Gainesville, FL. $3260 \%$

\begin{abstract}
Gravid mosquito traps are commonly used for both arbovirus surveillance and population surveillance of mosquitoes of the genus Culex. Oviposition substrates, used as baits in these traps, were tested against Culex under laboratory and field conditions. In the laboratory all substrates tested as $1 \%$ and $10 \%$ dilutions in 2-choice bioassays against female $C x$. quinquefasciatus were significantly more effective than well water controls in eliciting oviposition. Strongest responses were to dilutions of dairy effluent, followed by larval water and infusions of alfalfa hay, alfalfa pellets, Bermuda hay, oak leaves, and Typha leaves, with lowest responses to cow manure infusion. In the field, few significant differences in collections were obtained between traps baited with different infusions, Significantly more $C x$. quinquefasciatus and $C x$. nigripalpus were collected in traps baited with cow manure infusion (highest) compared to alfalfa hay infusion (lowest). Responses of $C x$. quincuefasciatus to dairy effluent and intusions of Bermuda hay, oak leaves, and Typha leaves were not signifisantly different from either cow manure infusion or alfalfa hay infusion. Responses of Cx. nigripulpus were highest to cow manure infusion and equally low to infusions of alfalfa hay and Typha leaves; moderate responses were observed to dairy effluent and infusions of Bermuda hay and oak leaves. Gravid females comprised 66.7 $81.9 \%$ of the collections for each infusion type, with no significant difference among infusions in the proportion of gravid females collected.
\end{abstract}

KEY WORDS Mosquito, organic infusion, oviposition attractant. Culex quinquefasciarus, Culex nigripalpus

\section{INTRODUCTION}

Mosquitoes in the genus $C$ ulex have been implicated as the primary vectors of West Nile virus and St. Louis encephatitis in North America (Day 2001, Goddard et al. 2002). Effective monitoring of these species is essential as part of effective control programs, as well as population and disease surveillance. Although conventional light traps collect many Culex spp., they may underrepresent some of the vector species present (Sudia et al. 1967, Nayar et al. 2001). Moreover, collections from light traps consist primarily of unfed females, which are less likely to contain virus than females that have bloodfed or are gravid. Gravid mosquito traps offer another approach for surveillance because they are designed to collect gravid, bloodfed female mosquitoes (primarily Culex spp.) that are attracted to approach a potential oviposition site (Reiter 1983). Collections from these gravid traps may contain from 57\% (Ritchie 1984) to 95\% (Reiter 1987) gravid females and these traps are often incorpo-

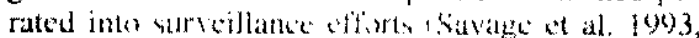
Nayar et al. 2001, Nasci et al. 2002)

Culex spp. generally oviposit in water high in organic matter and a wide array of oviposition substrates are reported as attractive to gravid females. These substrates may consist of naturally occurring materials such as water from field sites (natural or agricultural), rearing water, or organic infusions that consist of complex mixtures of compounds (Bentley and Day 1989). These compounds may be mosquito attractants, repellents, or both depending on concentration. Behaviorally active compounds are considered products of bacterial fermentation
(Ikeshoji et al. 1975. Beehler et al. 1994) and their composition and concentrations are dynamic through time. Sources of variability in composition of infusions may include source material (species of plant, age and quality of material, presence of weeds, and so on) and conditions of fermentation (temperature, darkness, duration, and so on) and this variability can confound comparisons between studies (Brust 1990, Lampman and Novak 1996) However, in the absence of standardized controlledrelease lures of known composition. infusions remain the most practical means for baiting gravid female traps.

Infusions that have been repurted as attractive to Culex spp. have been made by using materials such as hay (Reiter 1983), hay in conjunction with isopropyl alcohol (Ritchie 1984, Reisen and Meyer 1990), Bermuda hay (Isoe and Millar 1995), alfalfa hay (Reisen and Meyer 1990), grass and logs (Gjullin et al. 1965), sod (Brust 1990), alfalfa pellets

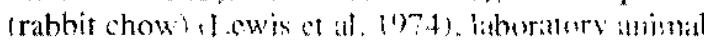
chow (Kramer and Mulla 19:9), bullrush (Du and Millar 1999, Reisen et al. 1999), chicken manure (Kramer and Mulla 1979), cow manure (Leiser and Beier 1982), horse manure (O'Gower 1963), and oak leaves (O'Meara et al. 1989). In trials in Lllinois (Lampman and Novak 1996) and California (Reisen and Meyer 1990), significant differences were observed between local Culex spp. in responses to a range of infusions. In this study we compared the effectiveness of various oviposition substrates reported in the literature on collection of Culex spp. in gravid female traps in Florida. 


\section{MATERIALS AND METHODS}

Culex quinquefasciatus Say was reared by using conventional methods with larvae at a standardized density and level of nutrition (1,000 immatures/3 liters of water and fed on a 1:1 mixture of liver powder and brewer's yeast) (Gerberg et al. 1994). Females were fed 5-7 days after emergence on manually defibrinated bovine blood and then held for 6 days at $27-29^{\circ} \mathrm{C}$ and $85-90 \%$ relative humidity under a photoperiod of $14: 10 \mathrm{~h}$ light: dark. A $10 \%$ sugar solution was provided continuously.

Infusions: Age of infusion can significantly influence mosquito response (Kramer and Mulla 1979, Brust 1990, Du and Millar 1999), so published protocols for preparation of effective oviposition substrates were followed. Bermuda hay infusion was prepared following Reiter (1983) and Millar et al. (1992) by adding $225 \mathrm{~g}$ of Bermuda grass hay (Cynodon dactylon), $10 \mathrm{~g}$ of brewer's yeast, and $10 \mathrm{~g}$ of lactalbumen hydrolysate to 40 liters of well water (at room temperature $25-27^{\circ} \mathrm{C}$ ), letting the mixture sit for 12 days. Bermuda grass hay was obtained from a local farm supplier. A]falfa hay infusion was prepared similarly to the Bermuda hay infusion except dried alfalfa hay (Kaytee Products Inc., Chilton, WI) was used. Infusions of cow manure were prepared by following Leiser and Beirer (1982) by adding $1.2 \mathrm{~kg}$ of fresh moist manure to 20 liters of well water and steeping for 7 days. Oak leaf infusion was prepared by following O'Meara et al, (1989) by adding $675 \mathrm{~g}$ of dried aak leaves (combination of live oak lQuercus virginina] and laurel oak [Quercus laurifolia]) to 19 liters of well water and steeping for 7 days. An infusion from alfalfa peilets was prepared by following Strickman (1988) by adding $32 \mathrm{~g}$ of alfalfa pellets (rabbit pellets, Kaytee Products Inc.) to 4 liters of well water and steeping for 11 days. An infusion was prepared similar to the bulrush infusion of Du and Millar (1999) except that we used cattail (Typha latifolia), a common local species. Leaves were collected, dried, and then $450 \mathrm{~g}$ was added to 20 liters of well water and steeped for 7 days. Water from an effluent lagoon at a commercial dairy that contained cow manure, egg rafts, and immatures (primarily $C x$, quinquefasciatus with low numbers of Culex nigripalpus Theobald) also was included as a treatment. This and adjacent lagoons were considered the primary sources of the populations of $C x$. quinquefasciatus at the commercial dairy. Water collected from the lagoon was sieved to remove particulate matter and immatures.

Larval water for use in laboratory bioassays was obtained from standard rearing practices for $C x$. quinquefasciatus (Gerberg et al. 1994), with larvae reared at a density of about 1,000 per liter of water. Larval water was collected just before larvae pupated (ca. 6 days). Infusions were made and allowed to ferment for the appropriate times and then frozen $\left(-20^{\circ} \mathrm{C}\right)$ in $50-\mathrm{ml}$ and 1 -liter aliquots for use in laboratory and field studies. Frozen aliquots of infusions have been used successfully in previous studies to overcome some of the inherent variability from batch to batch of infusion (Kramer and Mulla 1979, Isoe et al. 1995, Trexler et al. 1998, Du and Millar 1999).

Laboratory bioassays. Two-choice bioassays were conducted with gravid mosquitoes held in a cage with 2 cups as choices for oviposition sites, including 1 control cup (well water) and 1 treatment cup (infusion). Bioassays were conducted in Plexiglas ${ }^{(0)}$ bioassay cages $\left(30 \mathrm{~cm}^{3}\right)$ fitted with a cotton stockinette sleeve on one end and screening on the other end. Twenty female mosquitoes were verified gravid on a chill table, and then placed in bioassay cages. Sugar solution also was present in each bioassay cage. Infusions or water were placed in polypropylene cups $(120 \mathrm{ml}$, Sweetheart Cup Co., Owings Mills, MD) that were previously spray painted with a flat-black paint. To remove possible contaminants and odors from the paint, paint was allowed to dry for several days and the cups were thoroughly rinsed in well water before use. Two cups were placed approximately $12 \mathrm{~cm}$ apart in the center of each bioassay cage. The control cup contained $50 \mathrm{ml}$ of well water and the treatment cup contained $50 \mathrm{ml}$ of the test infusion. The positions of treatment and control cups were random (through use of a random number table [Zar 1999]). Frozen infusions were thawed immediately before use and diluted with warm well water to reach a temperature of $25-27^{\circ} \mathrm{C}$. Diluted infusions were used immediately for bioassays and not stored.

Bioassays were set up in late afternoon, treatments were placed in cages, and treatments were removed 22-24 h later. Bioassays were conducted at $26-29^{\circ} \mathrm{C}$ and a photoperiod of $14: 10 \mathrm{~h} \mathrm{light} \mathrm{:} \mathrm{dark}$ with $1 \mathrm{~h}$ of dusk. Bioassays were replicated 30 times with 6-10 replicates completed each day. Means of the replicates completed each day were compared by analysis of variance (ANOVA, SAS Institute 1999) to verify that no between-day differences existed before combining data. The positions of treatment and control cups (right or left) were noted and assigned randomly between the 2 positions. No position effect was present within any treatment (paired $t$-test, $P>0.05$ ). After removal from cages, the numbers of egg rafts in the treatment and control cups were counted, the total number of egg rafts deposited in each cage determined, and the percentage of egg rafts deposited in the treatment and control cups in each cage was calculated.

Field study: The field study was conducted at a commercial dairy farm in Marion County, Florida $\left(28^{\circ} 58^{\prime} \mathrm{N}, 82^{\circ} 24^{\prime} \mathrm{W}\right)$ at an effluent lagoon surrounded by grass (Digitana spp.), sedges (Cyperus spp.), and herbaceous vegetation (primarily Ambrosia artemisiifolia, Amaranthus hybridus, and Ipomoea trichocarpa). Traps at the farm were placed adjacent to the effluent lagoon. Vegetation was cleared ad- 
Table 1. Percentages (mean $\pm \mathrm{SE}$ ) of gravid Culex quinquefasciatus ovipositing in cups containing organic substrates or infusion (treatment) or well water (control) in a 2-choice laboratory assay ( $n=30$ replicates each with 20 mosquitoes).'

\begin{tabular}{llclllll}
\hline \hline & \multicolumn{3}{c}{$1 \%$ dilution } & & & \multicolumn{2}{c}{ 10\% dilution } \\
\cline { 2 - 3 } & Treatment & Control & $P$ & & Treatment & Control & $P$ \\
\hline Alfalfa hay & $76.4(3.5) \mathrm{b}$ & $23.6(3.5)$ & $<0.001$ & $74.1(3.5) \mathrm{b}$ & $25.9(3.5)$ & $<0.001$ \\
Alfalfa pellets & $80.4(2.3) \mathrm{b}$ & $19.6(2.3)$ & $<0.001$ & $75.8(4.8) \mathrm{b}$ & $24.2(4.8)$ & $<0.001$ \\
Bermuda hay & $82.6(3.5) \mathrm{ab}$ & $17.4(3.5)$ & $<0.001$ & $84.7(3.6) \mathrm{b}$ & $15.3(3.7)$ & $<0.001$ \\
Cow manure & $59.1(4.2) \mathrm{c}$ & $40.9(4.2)$ & $<0.001$ & $67.9(3.5) \mathrm{c}$ & $32.1(3.5)$ & $<0.001$ \\
Dairy effluent & $84.2(2.1) \mathrm{a}$ & $15.8(2.1)$ & $<0.001$ & $95.4(1.1) \mathrm{a}$ & $4.6(1.1)$ & $<0.001$ \\
Larval water & $83.9(2.7) \mathrm{ab}$ & $16.1(2.7)$ & $<0.001$ & $80.8(2.5) \mathrm{b}$ & $19.2(2.5)$ & $<0.001$ \\
Oak leaves & $74.3(4.8) \mathrm{b}$ & $25.7(4.8)$ & $<0.001$ & $84.2(2.3) \mathrm{b}$ & $15.9(2.3)$ & $<0.001$ \\
Typha leaves & $73.2(3.0) \mathrm{b}$ & $26.8(3.0)$ & $<0.001$ & $80.5(3.5) \mathrm{b}$ & $15.9(3.5)$ & $<0.001$ \\
Water & $50.5(4.6) \mathrm{d}$ & $53.9(4.7)$ & 0.123 & $50.5(4.6) \mathrm{d}$ & $53.9(4.7)$ & 0.123 \\
\hline
\end{tabular}

'Means in a column followed by the same letter are not significantly different $(P<0.05$, Tukey"s standardized test [SAS Institute 1999|).

jacent to traps and traps placed $0.25-0.5 \mathrm{~m}$ from the edge of lagoon.

The traps used for this study were Centers for Disease Control gravid traps (model 1712, John W. Hock Company, Gainesville, FL) supplied with a small green pan (ca. $22 \mathrm{~cm}$ wide $\times 34 \mathrm{~cm}$ long $\times$ $17 \mathrm{~cm}$ deep, Rubbermaid 439 , Rubbernaid ${ }^{\oplus 0 m-}$ mercial Products, Winchester, VA). Pans were preconditioned by filling with water and letting sit for at least $1 \mathrm{wk}$, then were scrubbed, rinsed, and dried before use. Traps were positioned at ca. $20 \mathrm{~m}$ intervals along the side of the dairy lagoon in Marion County and were moved daily among positions. Traps were not visible between positions. Each day batteries were replaced and traps were baited with 2 liters of freshly thawed infusion. Traps were evaluated for 12 nights and placed in the field at $1000-$ $1200 \mathrm{~h}$ and picked up 22-24 h later. Mosquitoes were returned to the laboratory; sorted to species, sex, and gonotrophic condition; and counted. Gonotrophic condition was classified by following Edman et al. (1975). Females containing blood but no developed eggs were considered bloodfed, those with fully developed eggs were considered gravid, and those with partially digested blood were classified as bloodfed if they contained more blood than eggs or gravid if they contained more eggs than blood. Mosquitoes too damaged for species identification were classified by genus.

Statistical analysis: Means presented in tables are untrastormed. Labonatury buotssay data (percentages) were arc-sine transformed and comparisons between treatments and controls were made with paired $t$-tests. Comparisons between treatments were made with PROC GLM (SAS Institute 1999) followed by means separations by using Tukey's standardized range test. Trap counts were transformed by $\log (x+1)$ before analysis. Data analysis was conducted by using PROC GLM with treatment and position effects and interactions tested. The percentages of gravid females in each trap were arc-sine transformed before being analyzed by
PROC GLM and tested for means separation by using Tukey's stanđardized range test.

\section{RESULTS}

\section{Laboratory bioassays}

Results are summarized in Table 1. Oviposition responses of female $C x$. quinquefasciatus in 2choice bioassays were significantly greater to all of the infusions compared to the water controls $(P<$ 0.001 ). Responses to water as a treatment were not different from those to water as a control $(P=$ 0.123 ). For comparisons between infusions, significant differences were present with both $1 \%$ dilutions (ANOVA; df $=8,261, \mathrm{~F}=51.97, P<0.001$ ) and $10 \%$ dilutions (ANOVA; $\mathrm{df}=8,261, \mathrm{~F}=5.51$, $P<0.001$ ). All infusions at both $1 \%$ and $10 \%$ dilutions elicited significantly more oviposition in the treatment cups than did the water controls (Table 1). The lowest oviposition responses to all infusions were to the $1 \%$ and $10 \%$ cow manure dilutions $(59.1 \%$ and $67.9 \%$, respectively). Responses were greatest at $1 \%$ dilution to the dairy effluent $(84.2 \%)$, Bermuda hay infusion $(82.6 \%)$, and larval water $(83.9 \%)$. Lower responses that were not significantly different from the Bermuda hay infusions and larval water were obtained in response to infusions of alfalfa pellets $(80.4 \%)$, alfalfa hay (76.4\%), oak leaves (74.3\%), and Typha leaves $(73.2 \%)$. At $10 \%$ dilution, responses followed a similar pattern, with the greatest response to dairy effluent $(95.4 \%)$. High responses also were obtained to Bermuda hay $(84.7 \%$ ), oak leaves $(84.2 \%)$, larval water $(80.8 \%)$, alfalfa pellets $(75.8 \%)$, and alfalfa hay $(74.1 \%)$. The lowest response to infusions was to the cow manure infusion (67.9\%).

\section{Field study}

Results are summarized in Table 2. In the field comparison of the effect of infusions on trap col- 
Table 2. Effect of infusion type on average daily collection (mean (SE)) of mosquitoes in Centers for Disease Control gravid traps placed on commercial dairy farm in Marion County, Florida.

\begin{tabular}{lcccccc}
\hline & Alfalfa hay & Bermuda hay & Cow manure & Dairy effluent & Oak leaves & Typha leaves \\
\hline Total female Culex & $68.3(8.6) \mathrm{b}$ & $146.3(19.6) \mathrm{ab}$ & $178.7(35.2) \mathrm{a}$ & $133.2(29.8) \mathrm{ab}$ & $143.1(30.7) \mathrm{ab}$ & $135.0(30.3) \mathrm{ab}$ \\
CX. quinquefasciatus & $40.6(5.1) \mathrm{b}$ & $98.6(16.9) \mathrm{ab}$ & $117.4(30.3) \mathrm{a}$ & $85.0(19.5) \mathrm{ab}$ & $90.7(20.1) \mathrm{ab}$ & $107.0(27.2) \mathrm{ab}$ \\
Cx. nigripalpus & $27.2(4.3) \mathrm{b}$ & $47.6(5.9) \mathrm{ab}$ & $70.8(13.8) \mathrm{a}$ & $48.2(11.8) \mathrm{ab}$ & $52.5(11.4) \mathrm{ab}$ & $30.0(3.5) \mathrm{b}$ \\
Total gravid female & & & & & & \\
$\quad$ Culex & $54.8(8.3) \mathrm{b}$ & $104.8(14.2) \mathrm{a}$ & $123.8(27.5) \mathrm{a}$ & $103.4(23.1) \mathrm{a}$ & $109.2(22.9) \mathrm{a}$ & $114.8(25.5) \mathrm{a}$ \\
Cx. quinquefasciatus & $31.0(5.6) \mathrm{b}$ & $72.6(13.0) \mathrm{ab}$ & $98.6(25.5) \mathrm{a}$ & $68.9(15.2) \mathrm{ab}$ & $68.9(13.8) \mathrm{ab}$ & $90.4(22.7) \mathrm{a}$ \\
Cx. nigripalpus & $24.8(3.4) \mathrm{b}$ & $32.2(3.0) \mathrm{ab}$ & $43.4(9.7) \mathrm{a}$ & $34.6(9.2) \mathrm{ab}$ & $37.5(8.9) \mathrm{ab}$ & $24.4(3.4) \mathrm{b}$ \\
Bloodfed females & $1.0(0.4) \mathrm{a}$ & $1.8(0.6) \mathrm{a}$ & $0.8(0.3) \mathrm{a}$ & $0.6(0.4) \mathrm{a}$ & $0.8(0.4) \mathrm{a}$ & $1.8(0.6) \mathrm{a}$ \\
Male Culex & $7.6(1.5) \mathrm{a}$ & $12.4(2.9) \mathrm{a}$ & $20.5(5.8) \mathrm{a}$ & $11.4(2.5) \mathrm{a}$ & $16.7(6.9) \mathrm{a}$ & $9.4(3.3) \mathrm{a}$ \\
Culex spp. & $0.1(0.1) \mathrm{a}$ & $0.6(0.5) \mathrm{a}$ & $2.7(0.5) \mathrm{a}$ & $2.8(0.7) \mathrm{a}$ & $5.7(4.2) \mathrm{a}$ & $2.8(0.5) \mathrm{a}$ \\
\hline
\end{tabular}

1 Means in a row followed by the same letter are not significantly different $(P<0.05$. Tukey's standardized test [SAS Institute 1999]).

lections, a total of 11,604 Culex were collected over 72 trap nights. The most common mosquitoes collected were female $C x$ quinquefasciatus $(58.7 \%)$ and $C x$. nigripalpus (31.9\%); however, low numbers $(<40)$ of Uranotaenia lowii Theobald, Aedes albopictus (Skuse), and Culex salinarius Coquillett also were present. The remaining collection consisted of males $(7.2 \%)$ and Culex that could not be identified $(1.6 \%)$.

Significant differences in trap collections existed between infusions for number of females $C x$. Quinquefasciatus, female $C x$. Nigripalpus, total female Culex, gravid $C x$ quinquefasciatus, gravid $\mathrm{Cx}$. Nigripalpus, and total gravid females $(P<0.01)$, but not for male Culex, or Culex spp. Relatively few bloodfed mosquitoes were collected in traps and no difference was found in numbers collected between traps with different infusions. Traps with cow manure infusions collected significantly more female Culex than those with alfalfa hay infusion. However, no difference was found in collections from traps with cow manure, Typha leaves, Bermuda hay, dairy effluent, and oak leaves. Collections of fernale $C x$. quinquefasciatus showed a similar trend. However, fewer female $C x$. nigripalpus were collected in traps with alfalfa hay and Typha leaves compared to cow manure. Significantly fewer gravid females were collected in traps baited with alfalfa hay compared to the other infusions. For $C x$. quinquefasciatus, significantly more gravid females were collected in traps baited with cow manure and Typher leaves compared to alfalta hay. However. no differences were found between cow manure and Typha leaves and Bermuda hay, dairy effluent, and oak leaves. Significantly fewer gravid $C x$. nigripalpus were collected in traps with alfalfa hay and Typha leaf infusions than with cow manure infusions. No difference was found in collections between traps with Bermuda hay, dairy effluent, oak leaves, or cow manure infusions. The portion of trap collections that represented gravid females ranged from $66.7 \%$ to $81.9 \%$, with no difference between infusions (PROC GLM; $\mathrm{df}=5,66, \mathrm{~F}=$ $0.86, P=0.51)$. No differences were found in col- lections of male Culex and bloodfed Culex between traps baited with different infusions.

\section{DISCUSSION}

In our laboratory studies, oviposition responses by $C x$. quinquefasciatus were high to all of the infusions except the cow manure infusion. The greatest responses were to the dairy effluent, with stronger responses at the $10 \%$ dilution compared to the $1 \%$ dilution. Effluent water likely contained a composite of potential oviposition attractants from several sources including cow manure, and high numbers of immatures and egg rafts. Cow manure provides a substrate for bacterial activity that could result in emission of attractant compounds. Attraction to water that contained larvae appeared to be associated with the presence of immature mosquitoes (Wilmot et al. 1987) and their associated bacterial fauna (Benzon and Apperson 1988). This has been reported in numerous species of Culex, such as Culex tarsalis Coquillet (Hudson and McLintock 1967), Culex pipiens molestus Forskal and Cx. tritaeniorhynchus summorosus Day (Nakamura 1978), $C x$. quinquefasciatus Say (Suleman and Shirin 1981), and Culex annulirostris Skuse and Culex molestus Forskal (Dhileepan 1997). An oviposition pheromone identified from egg rafts of $C x$. quinquefasciatus also is an oviposition attractant for several species of Culex (Laurence and Pickett 1985). Reisen and Meyer (1990) evaluated water from a latturt field site in haberatery alsisalys with mixed results and reported that it was only as attractive as tap water for oviposition by $C x$. quinquefasciatus and $C x$. tarsalis. Subsequently, Isoe and Millar (1995) evaluated field water from 2 sites and obtained significant oviposition by $C x$. tarsalis to water from only 1 of the sites. In their study, responses to the field water were similar to those to Bermuda grass infusion. In contrast, we obtained the highest responses to the dairy effuent from the lagoon that was also a field site for immatures. Differences between these studies may reflect differing levels of organic matter present at the study sites. 
Responses in our study to larval water were high but not significantly different from those to Bermuda hay infusion, which is generally considered a good oviposition attractant (Isoe and Millar 1995. Isoe et al. 1995). Although attractant compounds have been identified from Bermuda hay infusion (Millar et al. 1992), it is not known if the same compounds are responsible for the attraction to larval water. Attraction of gravid females to manure and the other infusions is likely due to compounds produced by the bacterial decomposition of the organic matter. Presumably differences between in fusions result from the composition and density of bacterial flora in conjunction with richness in organic matter as substrate. The lowest responses to infusions in our laboratory study occurred in response to cow manure with a slight increase in response $(<10 \%)$ with increase in concentration (from $1 \%$ to $10 \%$ ). In contrast. Reisen and Meyer. (1990) reported steer manure as the most attractive infusion for both $C x$. quinquefasciatus and $C x$. tarsalis. The difference in these results may be related to the difference in methods for preparation of the manure infusion because our infusion was made with moist rather the dry manure and fermented for 1 wk rather than 3 wk.

In laboratory studies, infusions were diluted and tested at $1 \%$ and $10 \%$ concentrations to reduce repellent effects at high concentration in small bioassay chambers. Testing at these dilutions generally provides representative comparisons of infusions (Kramer and Mulla 1979, Allan and Kline 1995, Isoe and Millar 1995, Du and Millar 1999).

Most of the infusions tested were highly effective for collection of both $C x$. quinquefasciatus and $C x$. nigripalpus in gravid female traps. In general, laboratory results with $C x$. quinquefasciatus supported the results in the field study except for the cow manure infusion. In laboratory assays, responses to this infusion were significantly lower than to the other infusions; however, under field conditions, traps with this infusion collected the greatest number of mosquitoes. One possible reason for the difference in responses could be due to concentration because the field tests were conducted with undiluted infusion and the laboratory tests were conducted with $1 \%$ and $10 \%$ dilutions of the infusions. The increased oviposition from $59.1 \%$ response (1\% cow manure infusion) to $67.9 \%$ response $(10 \%$ cow manure infusion) appears to support this. Many of the infusions were equally effective for collection of both $C x$. quinquefasciatus and $C x$. nigripalpus, with the lowest responses consistently to alfalfa hay infusions. A similar report of the lower responses to alfalfa hay infusion compared to Ber. muda hay infusion was reported by Isoe and Millar (1995).

Responses of gravid $C x$. quinquefasciatus and $C x$. nigripalpus to the infusions tested seemed rel. atively similar with the exception of the lower response of Cx. nigripalpus to the Typha infusion.
Although $C x$. quinquefasciatus and $C x$ nigripalpus may be present in the same larval habitat (as they were in this study), $C x$. quinquefasciatus generally is present in larval habitats that are higher in organic matter than those of $C x$. nigripalpus (Provost 1969). In studies by Reisen and Meyer (1990), responses by $C x$. tarsalis, a species associated with habitats with cleaner water than $C x$. quinquefasciatus, to infusions were very low compared to $C x$. quinquefasciatus. In field trials conducted by Lampman and Novak (1996) on attraction to infusions, appreciably lower responses were reported for Culex restuans Theobald, a species associated with less polluted larval habitats, than $C x$ pipiens. In our study, collections of immatures and eggrafts made in the adjacent dairy lagoon throughout the trapping period consisted of both $C x$. quinquefas" ciatus and $C x$. nigripalpus with $C x$. nigripalpus comprising one third or less of the collections (unpublished data). Trap collections of both species of Culex appeared to be representative of what was produced in the lagoon, with both species responding to the range of infusions tested.

In summary, a range of infusions was effective as baits in gravid female traps for collection of both $C x$. quinquefasciatus and Cx. nigripalpus. Infusions made with cow manure, oak leaves, and Bermuda hay were consistently attractive to both species and should serve as effective baits for gravid female traps for these species.

\section{ACKNOWLEDGMENT}

Thanks are extended to Mandi Falkner for assistance with this project.

\section{REFERENCES CITED}

Allan SA, Kline DL. 1995. Evaluation of organic infusions and synthetic compounds mediating oviposition in Aedes albopictus and Aedes aegypti (Diptera: Culicidae). J Chem Ecol 21:1847-1860.

Beehler JW, Millar JG, Mulla MS. 1994. Protein hydrolysates and associated bacterial contaminants as oviposition attractants for the mosquito Culex quinquefas. ciatus. Med Vet Entomol 8:381-385.

Bentley MD, Day JF, 1989. Chemical ecology and behavioral aspects of mosquito oviposition. Annu Rev Entomol 34:401-421.

Benzon GI. Apperson CS. 1988. Rexamination of chem-

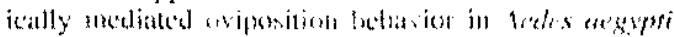
(L.)(Diptera: Culicidae). I Med Entomel 25:158-164.

Brust RA. 1990. Oviposition behavior of natural populations of Culex tarsalis and Culex restuans (Diptera: $\mathrm{Cu}$ licidae) in artificial pools. $J$ Med Entomol 27:248-255.

Day JF: 2001. Predieting St. Louis encephalitis virus epidemics: lessons from recent, and not so recent, outbreaks. Annu Rev Entomol 46:111-138.

Dhileepan K. 1997. Physical factors and chemical cues in the oviposition behavior of arboviral vectors Culex annulirostris and Culex molestus (Diptera: Culicidae). Environ Entomol 26:318-326.

Du Y, Millar JG. 1999. Electroantenogram and oviposition bioassay responses of $\mathrm{Culex}$ quinquefasciatus and $\mathrm{Cu}$ 
lex tarsalis (Diptera: Culicidae) to chemicals in odors from Bermuda grass infusions. I Med Entomol 36:158166

Edman JD. Cody E, Lymn H. 1975. Blood-feeding activity of partially engorged Culex nigripalpus (Diptera: Culicidae). Entomol Exp Appl 18:261-268.

Gerberg EJ, Barnard DR, Ward RA. 1994. Manual for mosquito rearing and experimental techniques. $A m$ Mosy Control Assoc Bull 5.98 p.

Gjullin CM, Johnson JO. Plapp FW Jr. 1965. The effect of odors released by various waters on the oviposition sites selected by two species of Culex. Mosq News 25: $268-271$.

Goddard LB, Roth AE, Reisen WK, Scott TW. 2002. Vector competence of California mosquitoes for West Nile virus. Emerg Infect Dis 8:1385-1391.

Hudson A. Mclintock. J. 1967. A chemical factor that stimulates oviposition by Culex tarsalis Coquitlet (Diptera: Culicidae). Anim Behav 15:336-341.

Ikeshoji T, Saito K, Yano A. 1975. Bacterial production of the ovipositional attractants for mosquitoes on fattyacid substrates. Ipn App/ Entomol Zool 10:239-242.

Isoe J, Beehler JW, Millar JG, Mulla MS. 1995. Oviposition responses of Culex tarsalis and Culex quinquefasciatus to aged Bermuda grass infusions. J Am Mosq Control Assoc 11:39-44.

Isoe J, Millar JG. 1995. Characterization of factors mediating oviposition site choice by Culex tarsalis, I Am Mosq Control Assoc 11:21;28.

Kramer WL. Mulla MS. 1979, Oviposition attractants and repellents of mosquitoes: oviposition responses of $\mathrm{Cu}$ lex mosquitoes to organic infusions. Environ Entomol 8:1111-1117

Lampman RL, Novak RJ. 1996. Oviposition preference of Culex pipiens and Cwlex restuans for infusion-baited traps. I Am Mosq Control Assoc 12:23-32.

Laurence BR, Pickett IA. 1985. An oviposition attractant pheromone in Culex quinquefasciatus Say (Diptera: $\mathrm{Cu}$ licidae). Bull Enromol Res 75:283-290.

Leiser BL. Beier JC. 1982. A comparison of oviposition traps and New Jersey light traps for Culex population surveillance. Mosq News 42:391-395.

Lewis LF, Clark TB, O'Grady JJ, Christenson DM. 1974. Collecting ovigerous Culex pipiens quinquefasciutus Say near favorable resting sites with lowvered traps baited with infusions of altalfa pellets. Mosq News 34:436 439.

Millar JG. Chaney JD, Mulla MS. 1992. Identification of oviposition attractants for Culex quinquefasciatus from Bermuda grass infusions, $J$ Am Mosq Control Assoc 8: $11-17$.

Nakamura H. 1978. Oviposition preference of Culex pipiens molestus and $C$. tritaeniorhyohus summorosus

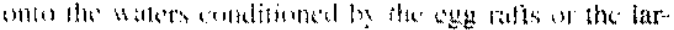
vae. Jph I Stuit 2 ow $29: 117-12,3$.

Nasci RS, Komar N, Marfin AA. Ludwig GV. Kramer LD, Daniels TJ, Falco RC. Campbell SR, Brookes K, Gottfried KL. Burkhalter KL, Aspen SE, Kerst AJ, Lanciotti RS. Moore CG. 2002. Detection of West Nile virus- infected mosquitoes and seropositive juvenile birds in the vicinity of virus-positive dead birds. Am J Trop Med Hyg 67:492-496.

Nayar JK. Karabatos N, Knight JW. Godsey M. Chang J. Mitchell CJ. 2001. Mosquito hosts of arboviruses from Indian River County, Florida during 1998. Fla Entomol 84:376-379.

O'Gower AK. 1963. Environmental stimuli and the oviposition behavior of Aedes aegypti var. queenlandis. Anim Behav 11:189-197.

O'Meara GF, Vose FE, Carlson DB. 1989. Environmental factors influencing oviposition by Culex (Culex) (Diptera: Culicidae) in two types of traps. $J$ Med Entomol 26:528-534.

Provost MW. 1969. The natural history of Culex nigripalpus. Fla State Board Health Monogr 12:46-62.

Reisen WK, Boyce K, Cummings RC, Delgado O, Gutiertez A. Meyer RP. Scott TW. 1999. Comparative effectiveness of three adult mosquito sampling methods in habitats representative of four different biomes of California. $J$ Am Mosy Control Assec 15:24-31.

Reisen WK. Meyer RP. 1990. Attractiveness of selected oviposition substrates for gravid Culex tarsalis and $\mathrm{Cu}$ lex quinquefasciatus in California. J Am Mosq Control Assoc 6:244-250.

Reiter P. 1983. A portable battery-operated trap for collecting gravid Culex mosquitoes. Mosq News 43:496498.

Reiter $P$. 1987. A revised version of the CDC gravid mosquito trap. $J$ Am Mosq Control Assnc 3:325-327.

Ritchie SA. 1984. Hay infusion and isopropyl alcoholbaited CDC light trap: a simple effective trap for gravic Culex mosquitoes. Mosq News 44: 404-407.

SAS Institute. 1999. SAS/STAT user's guide version \& Cary, NC: SAS Institute.

Savage HM, Smith GC. Moore CG, Mitchell CJ, Townsend M, Marfin AA. 1993. Entomological investigations of an epidemic of St. Louis encephalitis in Pine Bluff, Arkansas, 1991. Am / Trop Med Hyy 49:38-45.

Strickman D. 1988. Rate of oviposition by Culex quin. quefasciatus in San Antonio. Texas, during three years. $\checkmark$ Am Mosq Control Assoc 4:339-344.

Sudia WD. Coleman PH. Chamberlain RW, Wiseman JS. Work TH. 1967. St. Louis encephalitis vector studies in Houston, Texas. 1964. J Med Entomol 4:32-36.

Suleman M. Shirin M. 1981. Laboratory studies on oviposition behavior of Culex guinquefasciarus Say (Diptera: Culicidae); choice of oviposition medium and oviposition cycle. Bull Entomol Res 71:361-369.

Trexler JD. Apperson CS. Schal C. 1998, Laboratory and field evaluations of oviposition responses of Aedes albopictus and Aedes triseriatus (Diptera: Culicidae) to oak leaf infusions. $J$ Med Entomol 35:967-976.

Wilmut TR, Cope SF. Bar IR, los . The offect of immature mosquitues on oviposition by culex pipiens quinquefosciatus and Culiseta incidens (Diptera: Culicidae) in the field. Bull Soc Vector Ecot 12:512-516.

Zar JH. 1999. Biostatistical analysis thed. Upper Saddle River, NJ: Prentice Hall. 